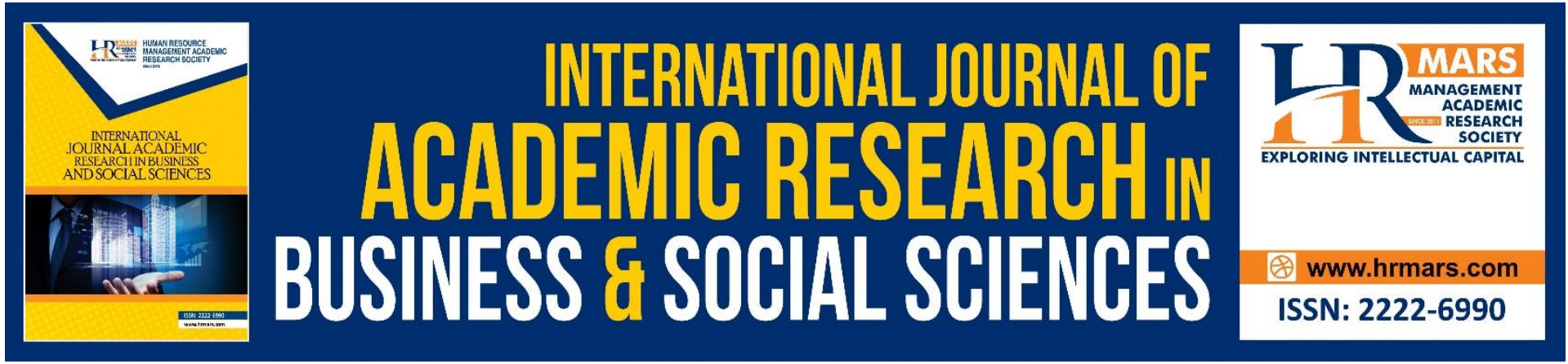

\title{
Challenges that Students Face at The University that May Require Counselling
}

Chebon Joan, Bargoria Finson, Kiptoo Wilson

To Link this Article: http://dx.doi.org/10.6007/IJARBSS/v11-i9/10968

DOI:10.6007/IJARBSS/v11-i9/10968

Received: 08 July 2021, Revised: 30 July 2021, Accepted: 20 August 2021

Published Online: 09 September 2021

In-Text Citation: (Joan et al., 2021)

To Cite this Article: Joan, C., Finson, B., \& Wilson, K. (2021). Challenges that Students Face at The University that May Require Counselling. International Journal of Academic Research in Business and Social Sciences, 11(9), 18-34.

Copyright: (c) 2021 The Author(s)

Published by Human Resource Management Academic Research Society (www.hrmars.com)

This article is published under the Creative Commons Attribution (CC BY 4.0) license. Anyone may reproduce, distribute, translate and create derivative works of this article (for both commercial and non-commercial purposes), subject to full attribution to the original publication and authors. The full terms of this license may be seen at: http://creativecommons.org/licences/by/4.0/legalcode

Vol. 11, No. 9, 2021, Pg. 18 - 34

http://hrmars.com/index.php/pages/detail/IJARBSS

JOURNAL HOMEPAGE

Full Terms \& Conditions of access and use can be found at http://hrmars.com/index.php/pages/detail/publication-ethics 


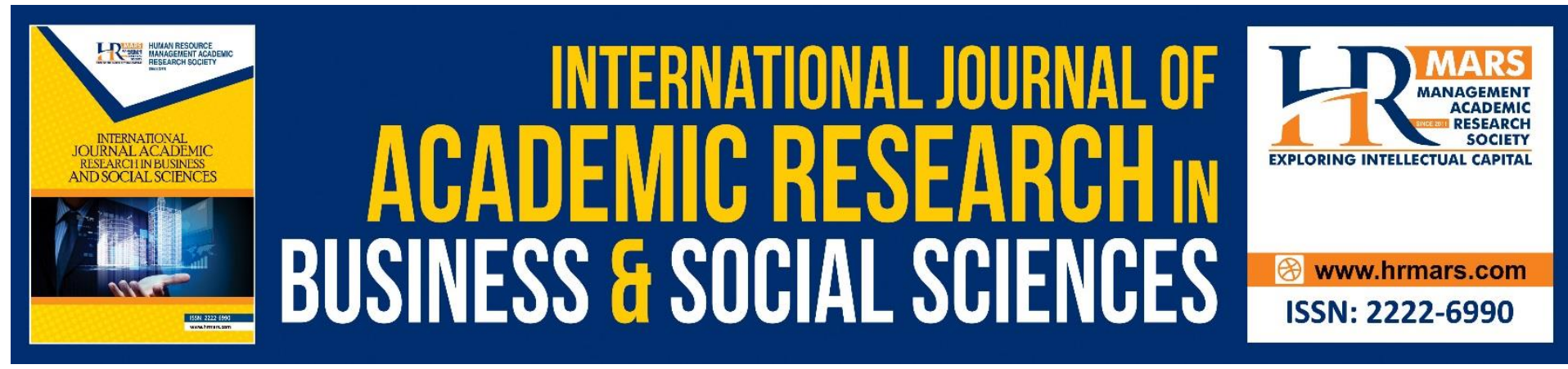

\title{
Challenges that Students Face at The University that May Require Counselling
}

\author{
Chebon Joan, Bargoria Finson, Kiptoo Wilson \\ Moi University, Kenya
}

\begin{abstract}
Attending college can be a stressful time for many students yet they do not seek professional help. This would lead to psychological distress and threatens their wellbeing. In spite of the implementation of counselling services in most public universities little has been done to assess the attitude, knowledge and perception of the professional counselling services among university students. Therefore, this study aimed at assessing the challenges that students face at the university that may require counselling. This study was undertaken at Moi University College of Health Sciences in Uasin Gishu County. It adopted a cross sectional survey design based on a sample drawn from across the year of study of Moi university students at the college of health sciences. The target population was 1147 out of this, a sample size of 288 students were the informers in the research. Fisher's formula was used to get the sample size. The study used stratified sampling technique to select participants, where the year of study formed the strata. Proportionate sampling was used to distribute the sample between schools. The sample per school was further proportionately distributed between the levels of study (year of study). The method for this study was schedule interviews and corresponding tool was schedule questionnaires. Data were analysed quantitatively using descriptive and inferential statistics. Descriptive statistics were in form of percentages and frequencies. ChiSquare was used to determine relationships between variables. The study found out that students of Moi University College of Health sciences were aware of professional counselling services offered at the university. The study concluded that students did not seek help because they felt capable of solving their own issues or getting help from their friends. It is recommended that the counselling department should be aware of the challenges facing students in order for them to advise accordingly.
\end{abstract}

Keywords: Challenges, Students, University, Counseling.

\section{Introduction}

Counselling is a process that is globally designed to help people understand and clarify personal views of their life space, and to learn to reach their self-determined goals through meaningful, well-informed choices and a resolution of problems of an emotional or interpersonal nature (Saban, 2003). It believes that every human individual has the potential for self-growth, self-development and self-actualization (Hanson, 1998). Professional counsellors offer confidential services that focus on the developmental and situational problems of persons of all ages and various multicultural backgrounds (Hasin et al., 2005). 
Globally, Professional counselling started in America at the beginning of 20th Century as a reaction to changes taking place in industrialized societies. The growth and development of the counselling profession worldwide is closely associated with the evolution of traditional societal structures caused by multiple social and economic factors over the last 20 years. Counselling services were set up in September 1968 when the recommendations made by Louis, a consultant sent over to Malta by United Nation's Educational Scientific and Cultural Organization (UNESCO), were taken up. Counselling services are essential elements in discipline management in societies. It would be difficult for any society to function without the exercise of discipline (Horwitz, Widom \& White, 2001). Historically, the notion of consulting with a stranger about personal or family problems was an unusual concept and even frowned upon. Social challenges that might cast a shadow on the name and reputation of the family had resolved privately.

In Africa, a person experiencing an interpersonal problem would seek the help of a wellrespected relative or a clan elder, while in most serious cases, traditional healers were consulted. A key element to the success of this process was societal structural stability which was influenced by the geographical location and proximity of those who would provide the services. Post-University counselling program has been introduced to assist students overcome the numerous challenges they experience at home and in school (Fall et al., 2000). Although counselling was formally introduced in Kenya in 1967, under the Ministry of Education, it has been engraved in the African traditional society since time immemorial. The Gachathi Report recommended that the Ministry of Education should take charge of delivering counselling services in schools (G.O.K, 2012). Despite these recommendations, the use of counselling services was doing little to stop the mounting cases of indiscipline in schools. It is now vital to borrow the concept of formal counselling from the western world to meet the social changes in our society. Thampy, \& Danczak (2015) argues that due to educational and economic challenges they have to grapple with, parents who are left with no time to positively parent their children

Most medical students around the world experience mental ill health whereby they feel not fully supported by their respective medical schools. Research conducted in United Kingdom among various medical students, found out that $30 \%$ of the respondents declared they had experienced or received treatment for a mental health condition while at medical school (WHO, 2003). From this group, 80\% thought the level of support available to them was either poor or only moderately adequate to their counselling needs $15 \%$ of the respondents also revealed that they had considered committing suicide at some point during their studies (WHO, 2003).

Most of the university students need psychological help, but they do not prefer to seek professional help. Those affected mostly are the mmedical school students due to the stressful environment that affects their academic, physical and psychological wellbeing (Fawzy \& Hamed, 2017). Medical students unlike the general student's population encounter human suffering and traumatic events at a high frequency hence sufficient psychological distress (Kennedy, Kenny \& O'Meara, 2015). Medical students unlike other undergraduate students undergo intensive and involving program which includes ward rounds in the hospital on a daily basis which subjects them to psychological trauma.

Psychological distress which is not dealt with successfully threatens the well-being of these students, disrupts their lives even causing more severe mental health problems. When students seek help, they prefer mostly their friends and then family members who also affect their professional help-seeking decisions (Farberman, 1997). According to study done by 
Chesire (2012) on prevalence and predisposing factors of depression among medical students in Kenya universities indicated that many medical students don't utilize counselling services. The study recommended that there is need to further study why underutilization of counselling services. Therefore, by assessing knowledge, attitude and perception of students on professional counselling services in the college of health sciences, Moi University, more information may be obtained about help-seeking behaviour of university students.

\section{Objective of the Study}

The objective of the study was to assess the challenges that students face at the university that may require counselling.

\section{Research Hypothesis}

i. Which challenges do students face at the university that require counselling?

\section{Literature Review}

\section{Challenges that Students Face at the University that May Require Counselling}

University students are adolescents and young adults who face tremendous pressure to adjust to the new environment. Students who join the University face different challenges. Adapting to the social and the physical environment constitutes one of the main challenges. Adjustment to new peer groups, academic atmosphere, loose family contact, and financial problems are some of the specific challenges (Bowers et. al., 2002). These challenges possibly lead students to personal crisis, mainly emotional disturbance, stress, and another social crisis. These mainly lead to academic failure, drug addiction, social isolation, suicidal attempts and the like. In relation to these problems, the need for student orientation, professional counselling services is crucial. In addition to these services, the University has decided to issue comprehensive guidelines necessary to establish a university wide Centre for Orientation, Professional counselling services and other centres in each university, school, and institute.

University students, who start university after completing high school immediately, are typically younger, depend on parents for financial support, and do not work or work part-time (Dent, 2013). Stress related to academic load, these kinds of students may have to face the task of taking on more adult-like responsibilities without having yet mastered the skills and cognitive maturity of adulthood. Many of university students who joined immediately after high school may face potentially stressful experiences for the first time in their life. This stressful experience may include; working, being in a significant relationship that may lead to marriage, or having housemates with cultures and belief systems different from their own (Huddleston, et. al., 2013).

Non-traditional university students are often employed full-time, older, and may have dependents other than their spouses (Bowers et al., 2002). Thus, this group of students may have to cope with meeting work and family demands in addition to academic requirements. Therefore, many university students may experience the persistence, exacerbation, or first onset of mental health and substance use problems while possibly receiving no or inadequate treatment. With the increasing recognition of child mental health issues and the use of more psychotropic medications, the number of young adults with mental health problems entering university has significantly increased.

A survey carried out in 274 institutions by Kitzrow (2009) indicated that $88 \%$ of counselling centre directors reported an increase in "severe" psychological problems over the previous 5 
years including learning disabilities, self-injury incidents, eating disorders, substance use, and sexual assaults. Thus, there is an increase in demand for counselling and specialized services. However, the increase in demands has not always corresponded to an increase in staff Kitzrow (2009). In particular, counselling centres are in need of psychiatrists with expertise in treating traditional as well as non-traditional university students, two groups with specific age-related characteristics and challenges.

According to Eisenberg, Hunt and Speer (2013) the common mental health problem among university students is depression, with prevalence rates in university students of 7 to $9 \%$. They found out that over half of all cases of depression had a first onset during childhood, adolescence, or young adulthood. Similarly, others have shown an elevated risk for mood disorders beginning in the early teens increasing with age in a linear fashion. In the National Comorbidity Survey-Replication study, Kessler et al (2005) reported that one out of every five individuals with depression had their first episode by the age of 25 years. The onset of bipolar disorder (BAD) appears to follow a similar trend. Approximately $3.2 \%$ of university students meet the criteria for BAD. An emerging literature has shown that the majority of adults with $B A D$ have the onset of their disorder in child and adolescent years, with at least a third of adults with BAD having their onset before the age of 12 years.

Binge drinking is considered the number one public health hazard and the primary source of preventable morbidity and mortality for university students in the USA. Among university students, alcohol consumption is associated with motor vehicle accidents, another leading cause of death in this age group Marlatt (2010), accidental injuries, unsafe sex, sexual assaults, and poor schoolroom performance, as well as impairments in prefrontal cortex functions such as memory and attention.

University students who drink heavily are approximately ten times more likely to use marijuana than those that are light drinkers (O'Grady et al., 2008). Data from the National University Health Risk Behaviour Survey shows that binge drinking students are nine times more likely to report lifetime use of marijuana than their non-binge drinking peers. The increased risk for using illicit substances among binge drinkers has serious implications, given that alcohol use in combination with drug use is known to increase substance-related negative consequences, even when controlling for level of drinking (Eisenberget al., 2013).

In addition to substance use and hazardous alcohol use, university students often engage in non-medical use (or misuse) of prescription medications, namely taking prescription medications without a prescription or taking more than prescribed. Although in the past 2 years, the rates of non-medical use of pain relievers among young adults have decreased, they continue high (Eisenberget al. 2013). According to the National Survey on Drug Use and Health, approximately one in ten young adults reported non-medical use of pain relievers in the past year (National Survey on Drug Use and Health, 2012). Data suggest that the most commonly misused medications among university students include opioids, benzodiazepines (sedative/hypnotics), and amphetamine/methylphenidates (stimulants), with 5-35\% of university students having misused stimulants (Biederman et.al., 2008).

\section{Theoretical Framework \\ Cognitive Theory}

This study will adopt Cognitive Theory. The theory was developed by psychotherapist Aaron Beck in the 1960s. The theory of Cognitive therapy is based on the cognitive model, which states that thoughts, feelings and behavior are all connected, and that individuals can move toward overcoming difficulties and meeting their goals by identifying and changing unhelpful 
or inaccurate thinking, problematic behavior, and distressing emotional responses. This process involves the individual working collaboratively with the therapist to develop skills for testing and modifying beliefs, identifying distorted thinking, relating to others in different ways, and changing behaviors (Beck, 2008).

Cognitive behavioral therapy (CBT) can be used to treat people with a wide range of mental health problems. CBT is based on the idea that how we think (cognition), how we feel (emotion) and how we act (behavior) all interacts together. Specifically, our thoughts determine our feelings and our behavior. Therefore, negative and unrealistic thoughts can cause us distress and result in problems. When a person suffers with psychological distress, the way in which they interpret situations becomes skewed, which in turn has a negative impact on the actions they take (Dobson \& Block, 1988). Cognitive therapist helps people to develop alternative ways of thinking and behaving which aims to reduce their psychological distress. Cognitive behavioral therapy is, in fact, an umbrella term for many different therapies that share some common elements.

There is a major aid in cognitive therapy by what is known by Ellis (1957) ABC Technique of Irrational Beliefs. This is further analyzed by the following ways:

$\checkmark$ A-This denotes for Activating Event or objective situation. An event that ultimately leads to some type of high emotional response or negative dysfunctional thinking

$\checkmark$ B-Beliefs. This is whereby the client writes down the negative thoughts that occurred to them.

$\checkmark$ C - Consequence. This is for the negative feelings and dysfunctional behaviors that ensued. The negative thoughts are seen as a connecting bridge between the situation and the distressing feelings. This could be anger, sorrow, and anxiety, among others.

Cognitive behavioral therapy is important to this study because the model has great appeal as it focuses on human thought. Human cognitive abilities have been responsible for our many accomplishments so may also be responsible for our problems.

Again, this theory is relevant to current study because in every counseling situation, there are activating events (which Ellis calls factor $A$ ) that are not pleasant in nature. This can be an event, or the behavior, or an attitude of a student or individual. These events cause one to have self-analysis and therefore self-interpretation, which in turn causes one to form beliefs towards something or someone. For example, a student's challenges influence their attitude and perception towards seeking professional counseling services. It is the duty of counselors to offer intervention to correct the situation at the belief formation stage which Ellis calls disruptive interventions.

In conclusion this study utilizes the cognitive perspective to explain what is going on inside the mind of a person. The mind of human beings works like a computer as it processes information. Mind of human store and organize experiences into patterns called schemas, which helps human to interpret new experiences with cognitive efficiency. Self-regulation assumes that behaviours are directed from within the person. Self-regulation emphasizes the importance of goals and the process of feedback control.

\section{Research Methodology Research Design}

The current study adopted cross sectional survey design based on a sample drawn from across the year of study of Moi university students in the college of health sciences. 


\section{Study Area}

The research was carried out at Moi University, College of Health Sciences in Uasin Gishu County.

\section{Target Population}

The target population for this study was Moi University College of Health Sciences students. Therefore, the target populations for the study were picked from 1147 students in the college of health sciences.

\section{Sample Size and Sampling Technique}

The researcher obtained sample size using the Fishers formulae. According to this formula, a research study with a target population of less than 10,000 was used to calculate the sample size. The sample size of the study was calculated using the formula below as recommended by (Singh, \& Tailor, 2003; Cochran, 1940).

$$
n f=\frac{n}{1+\frac{n}{N}}
$$

Where;

$\mathrm{NF}=$ Sample size (when the population is less than 10,000).384

$\mathrm{n}=$ Sample size (when the population is less than 10,000);

$\mathrm{N}=$ the population size; 1147

Therefore, the sample size for this study was calculating as follows;

$\mathrm{NF}==\frac{384}{1+\frac{384}{1147}}$

$\mathrm{NF}=288$

This study therefore set out to sample 288 respondents

The study used stratified sampling technique where the schools formed the strata. Proportionate sampling was used to distribute the sample between schools. The sample per school was further proportionately distributed between the levels of study (year of study). This enhanced distribution representation and avoids bias in sampling. Sample of 288 health Science students was selected by use of this method.

Simple Random Sampling technique on a Yes/ No basis selection was used in the final selection of the health Science students according to distribution above. This is because all health Science students belong to the same college, which is the area of the study and they turn to have equal opportunity selected, and given in mind that these students belong to different social, cultural and economic backgrounds and the probability of each one of them being chosen is standing at equal chance.

\section{Scheduled Questionnaires}

A schedule is a set of questions with structured answers to guide an observer interviewer, researcher or investigator (Jamshed, 2014). It is a plan or guide line for investigation. According to, Carson (2010), the schedule is a list of questions which is necessary to test the hypothesis. In simple words, a schedule is a set of questions formulated and presented with specific purpose for testing an assumption or hypothesis. Schedule interviews are a set of questions with structured answers to guide an interviewer. The study used this method because it leads to more responses; accurate information's can be collected, it is free from 
biasness, personal contact between the investigator and respondent, more difficult situation can be studied and it is used for educated as well as uneducated respondents.

The study used primary data which was collected through Scheduled questionnaires. The Scheduled questionnaires were used to collect data on knowledge, attitude and perception of students on professional counselling services among Moi university students in the college of health sciences. The Scheduled questionnaires consisted of both open and closed ended questions designed to elicit specific responses for qualitative and quantitative analysis respectively. The questionnaires were administered by the researcher. The researcher opts to use questionnaires so as to collect a lot of information over a very short period of time. Further questionnaires compared with other data collection techniques were less costly to administer as supervision or follow up of respondents was not required. Pre-testing of questionnaires in the field was used as a means of improving the quality of questions before the main study (Jamshed, 2014).

\section{Data Analysis and Presentation}

This refers to the critical examination of the coded data and making inferences (Kombo and Tromp, 2006). The data were analysed quantitatively. Quantitative data were analysed using Statistical Package for Social Sciences (SPSS) where descriptive statistics and inferential statistics were used. Descriptive statistics were done in form of percentages and frequencies. Chi-Square was used to determine relationships between variables. Data were presented in form of frequency Tables.

\section{Research Findings and Discussions}

This chapter presents data analysis, presentation, interpretation and discussion of the findings

\section{Demographic Characteristics of the Respondents}

The study sought to determine the demographic information of respondents in order to cross tab with the study variables. The demographic information sought in this study was; gender, by areas of specialization, year of study, marital status and religion of the respondents. Out of a total of 288 sampled participants only 274 responded to study questions. This means that 14 did not participate in the study. This implies that $95.14 \%$ participated in the study implying that the data collected were justified to be used for analysis as indicated by Mugenda and Mugenda (2003) that a response rate of $70 \%$ and above is justifiable to be used for the study.

\section{Distribution of Respondents by Gender}

The study examined on the distribution of respondents by their gender and analysis results are as shown in Table 5.

Table 5 Gender of the Respondents

\begin{tabular}{llll}
\hline Gender & & Frequency & Percent \\
\hline Valid & Male & 124 & 45.3 \\
& Female & 150 & 54.7 \\
& Total & 274 & 100.0 \\
\hline
\end{tabular}

Source: Field Data (2018)

From Table 4.1 shows that 124 (45.3\%) of the respondents were male while 150 (54.7\%) were female. An implication that there was no biasness since both genders were well represented. 
This also helped in understanding which gender had knowledge, perception and attitude on professional counselling services.

\section{Distribution of Respondents by Areas of Specialization}

The study examined the areas of specialization of respondents by their level of education and the results of analysis are shown in Table 6.

\section{Table 6 Areas of Specialization}

\begin{tabular}{llll}
\hline \multicolumn{2}{l}{ Areas of specialization } & Frequency & Percent \\
\hline Valid & Bsc. Medicine & 115 & 42.0 \\
& Bsc. Nursing & 96 & 35.0 \\
& Bsc. Public Health & 45 & 16.4 \\
Bsc. Dentistry & 18 & 6.6 \\
& Total & 274 & 100.0 \\
\hline
\end{tabular}

Source: Field Data (2018)

Table 6 shows that majority $115(42.0 \%)$ of the respondents were pursuing a degree in medicine while the least were pursuing a degree in dentistry 18 (6.6\%).

\section{Distribution of Respondents by Age}

The study examined the distribution of respondents in regards to their age bracket. The results of analysis are shown in Table 7.

Table 7 Age of Respondents

\begin{tabular}{llll}
\hline Age & Frequency & Percent \\
\hline Valid & $15-19$ years & 61 & 22.3 \\
& $20-24$ years & 168 & 61.3 \\
& $25-29$ years & 34 & 12.4 \\
& $30-34$ years & 11 & 4.0 \\
& 40 and above years & 0 & 0.0 \\
& Total & 274 & 100.0 \\
\hline
\end{tabular}

Source: Field Data (2018)

The Table 7 shows that 61 (22.3\%) of the respondents were of $15-19$ years, while $168(61.3 \%)$ were between 20 - 24 years, 34 (12.4\%) 25-29 years and 11 (4.0\%) above 30 - 34 years. This implies that majority of respondents joining college of health science were relatively young having just finished their secondary school education.

\section{Distribution of Respondents by Year of study}

The study sought to examine the distribution of respondents basing on year of study. The results of analysis are shown in Table 8. 
Table 8 Year of Study of the Respondents

\begin{tabular}{llll}
\hline Year of study & & Frequency & Percent \\
\hline Valid & Year 1 & 72 & 26.3 \\
& Year 2 & 53 & 19.3 \\
& Year 3 & 131 & 47.8 \\
& Year 4 & 18 & 6.6 \\
& Total & 274 & 100.0 \\
\hline
\end{tabular}

Source: Field Data (2018)

The Table 8 indicated that $72(26.3 \%)$ of the respondents were in year $1,53(19.3 \%)$ of respondents were in year 2,131 (47.8\%) of respondents were in year 3 and $18(6.6 \%)$ were in year 4. This implies that most of the respondents were in year 3 of their studies implying that they understood the problems undergone by students in the university.

\section{Distribution of Respondents by Marital Status}

The study sought to examine the distribution of respondents based on their marital status. The results of analysis are shown in Table 9.

Table 9 Marital Status

\begin{tabular}{llll}
\hline Marital status & & Frequency & Percent \\
\hline Valid & Single & 237 & 86.5 \\
& Married & 37 & 13.5 \\
& Divorced & 0 & 0.0 \\
& Separated & 0 & 0.0 \\
& Total & 274 & 100.0 \\
\hline
\end{tabular}

Source: Field Data (2018)

The Table 9 shows that 237 (86.5\%) of the respondents were single while 37 (13.5\%) were married.

\section{Distribution of Respondents by Religion}

The study sought to examine the distribution of respondents based on religion. The results of analysis are shown in Table 10.

Table 10 Religion of the Respondents

\begin{tabular}{llll}
\hline Religion & & Frequency & Percent \\
\hline Valid & Christian & 264 & 96.4 \\
& Islam & 10 & 3.6 \\
& Hindu & 0 & 0.0 \\
& Total & 274 & 100.0 \\
\hline
\end{tabular}

Source: Field Data (2018)

The Table 10 shows that 264 (96.4\%) of the respondents were Christians, while $10(3.6 \%)$ of the respondents were Islam.

\section{Field Results}

The study first examined the challenges that students at Moi University College of Health Sciences faced. The results are presented herein below: 


\section{University Student's Challenges}

The study sought to assess the challenges that students face at the university that may require seeking of professional counselling. The researcher collected multiple responses from the participant. This is because the students face more than one challenge while in school. The study results were presented in Table 11 and shows that students various challenges were: financial, social and interpersonal, academic and drug and substance.

\section{Table 11 University Student's Challenges}

\begin{tabular}{l}
\hline University Student's Challenges \\
\hline Financial \\
Social and Interpersonal \\
Academic \\
Drug and Substance
\end{tabular}

\section{Source: Field Data (2018)}

\section{Gender and University Student's Challenges}

The study sought to cross tabulate gender and University student's challenges as well as chi square test. The study results were presented in Table 12.

Table 12 Gender and challenges Cross tabulation

\begin{tabular}{|c|c|c|c|c|}
\hline \multicolumn{2}{|l|}{ Challenges } & \multicolumn{2}{|l|}{ Gender } & \multirow{3}{*}{$\begin{array}{l}\text { Total } \\
231\end{array}$} \\
\hline & & \multirow{2}{*}{$\begin{array}{l}\text { Female } \\
107\end{array}$} & \multirow{2}{*}{$\begin{array}{l}\text { male } \\
124\end{array}$} & \\
\hline Financial & Count & & & \\
\hline & $\%$ of Total & $46.3 \%$ & $53.7 \%$ & $100.0 \%$ \\
\hline \multirow[t]{2}{*}{ Social and Interpersonal } & Count & 80 & 124 & 204 \\
\hline & $\%$ of Total & $39.2 \%$ & $60.8 \%$ & $100.0 \%$ \\
\hline \multirow[t]{2}{*}{ Academic } & Count & 73 & 124 & 197 \\
\hline & $\%$ of Total & $37.1 \%$ & $62.9 \%$ & $100.0 \%$ \\
\hline \multirow[t]{2}{*}{ Drug and Substance } & Count & 37 & 103 & 140 \\
\hline & $\%$ of Total & $26.4 \%$ & $73.6 \%$ & $100.0 \%$ \\
\hline Pearson Chi-Square X (Cal) ${ }^{2}$ & $x^{2}=30.165$ & $d f=1$ & \multicolumn{2}{|c|}{$p=0.000<0.05$} \\
\hline
\end{tabular}

\section{Source: Field Data (2018)}

The study findings in Table 12 indicated that out of 231 students who face financial challenges while in campus 124 (53.7\%) were male students and 107 (46.3\%) were female students. Out of 204 students who faces social and interpersonal challenges in campus 80 (39.2\%) were female and $124(60.8 \%)$ were male students. Students who faces academic challenges in campus were 197 and out of these 73 (37.1\%) were female students and 124 (62.9\%) were male students. Table 4.8 further revealed that out of 140 students who faces drugs and substance challenges in campus 37 (26.4\%) were female and 103 (73.6\%) were male students. This implies that both genders experienced different challenges while at campus. Pearson chisquare test was then administered to establish whether there is an association between gender and challenges faced. Pearson Chi-Square $X\left(\right.$ Cal) ${ }^{2}$ value was less than $p$ value $(p=0.000<0.05)$ which indicated that there was a significant relationship between gender and challenges faced by university students. 
The study findings disagree with Starovoytova \& Cherotich (2016) findings that genderrelated challenges in learning technical courses are universal phenomenon. These challenges could restrain female students from achieving their fullest potential. It is apparent, that the female students, indeed, faced numerous gender-related challenges and even harassment from teachers and classmates in studying.

\section{Area of Specialization and University Student's Challenges}

The study sought to cross tabulate area of specialization and University student's challenges and chi square test. The study results were presented in Table 13

Table 13 Area of Specialization and University Student's Challenges

\begin{tabular}{|c|c|c|c|c|c|c|}
\hline & \multirow[b]{2}{*}{$\begin{array}{l}\text { Bsc. } \\
\text { Medicine }\end{array}$} & \multirow[b]{2}{*}{$\begin{array}{l}\text { Bsc. } \\
\text { Nursing }\end{array}$} & \multirow[b]{2}{*}{$\begin{array}{l}\text { Bsc. } \\
\text { Public } \\
\text { Health }\end{array}$} & \multirow[b]{2}{*}{$\begin{array}{l}\text { Bsc. } \\
\text { Dentistry }\end{array}$} & \multirow[t]{2}{*}{ Total } \\
\hline & & & & & & \\
\hline \multirow[t]{2}{*}{ Financial } & Count & 81 & 87 & 45 & 18 & 231 \\
\hline & $\%$ of Total & $35.1 \%$ & $37.7 \%$ & $19.5 \%$ & $7.8 \%$ & $\begin{array}{l}100.0 \\
\%\end{array}$ \\
\hline \multirow{2}{*}{$\begin{array}{l}\text { Social and } \\
\text { interpersonal }\end{array}$} & Count & 61 & 80 & 45 & 18 & 204 \\
\hline & $\%$ of Total & $29.9 \%$ & $39.2 \%$ & $22.1 \%$ & $8.8 \%$ & $\begin{array}{l}100.0 \\
\%\end{array}$ \\
\hline \multirow[t]{2}{*}{ Academic } & Count & 54 & 80 & 45 & 18 & 197 \\
\hline & $\%$ of Total & $27.4 \%$ & $40.6 \%$ & $22.8 \%$ & $9.1 \%$ & $\begin{array}{l}100.0 \\
\% \\
\end{array}$ \\
\hline \multirow{2}{*}{$\begin{array}{l}\text { Drugs and } \\
\text { substance }\end{array}$} & Count & 16 & 61 & 45 & 18 & 140 \\
\hline & $\%$ of Total & $11.4 \%$ & $43.6 \%$ & $32.1 \%$ & $12.9 \%$ & $\begin{array}{l}100.0 \\
\%\end{array}$ \\
\hline $\begin{array}{l}\text { Pearson Chi- } \\
\text { Square } X(\text { Cal })^{2}\end{array}$ & $X^{2}=31.350$ & $d f=3$ & \multicolumn{4}{|c|}{$p=0.000<0.05$} \\
\hline
\end{tabular}

\section{Source: Field Data (2018)}

The study findings in Table 13 indicated that out of 231 students who face financial challenges, 81 (35.1\%) were from Bsc. Medicine, 87 (37.7\%) were from Bsc. Nursing, 45 (19.5\%) were from Bsc. Public health and 18 (7.8\%) were from Bsc. Dentistry. Further it indicated that out of 204 students who faces social and interpersonal challenges 61 (29.9\%) were from Bsc. Medicine. 80 (39.2\%) were from Bsc. Nursing, 45 (22.1\%) were from Bsc. Public health and 18 (8.8\%) were from Bsc. Dentistry. Out of 197 students who faces academic challenges 54 (27.4\%) were from Bsc. Medicine, 80 (40.6\%) were from Bsc. Nursing, 45 (22.8\%) were from Bsc. Public health and $18(9.1 \%)$ were from Bsc. Dentistry. Out of 140 of students who faces Drugs and substance challenges 16 (11.4\%) were from Bsc. Medicine, 61 (43.6\%) were from Bsc. Nursing, 45 (32.9\%) were from Bsc. Public health and 18 (12.9\%) were from Bsc. Dentistry. Pearson chi-square test was then administered to establish whether there is an association between area of specialization and university student's challenges. Pearson Chi-Square X (Cal) ${ }^{2}$ value was found to be less than $p$ value $(p=0.000<0.05)$ which indicated that there was a significant relationship between area of specialization and university student's challenges. 
The study findings concur with Davelaar et al (2005) noted that in the medical educational sphere, nursing students face more challenges than others as they progress in their course. They face financial hardship, staff insensitivity to cultural issues, discrimination, lack of Indigenous mentors, poor study skills, lack of adequate educational preparation, lack of resources and ongoing family commitments.

\section{Year of Study and University Student's Challenges}

The study sought to cross tabulate year of study and University student's challenges as well as chi square test. The study results were presented in Table 14.

Table 14 Year of Study and University Student's Challenges

\begin{tabular}{|c|c|c|c|c|c|c|}
\hline & \multicolumn{4}{|c|}{ Year of Study } & \multirow[t]{2}{*}{ Total } \\
\hline & & Year 1 & Year 2 & Year 3 & Year 4 & \\
\hline \multirow[t]{2}{*}{ Financial } & Count & 29 & 53 & 131 & 18 & 231 \\
\hline & $\%$ of Total & $12.6 \%$ & $22.9 \%$ & $56.7 \%$ & $7.8 \%$ & $100.0 \%$ \\
\hline \multirow{2}{*}{$\begin{array}{l}\text { social and } \\
\text { interpersonal }\end{array}$} & Count & 7 & 48 & 131 & 18 & 204 \\
\hline & $\%$ of Total & $3.4 \%$ & $23.5 \%$ & $64.2 \%$ & $8.8 \%$ & $100.0 \%$ \\
\hline \multirow[t]{2}{*}{ Academic } & Count & 7 & 41 & 131 & 18 & 197 \\
\hline & $\%$ of Total & $3.6 \%$ & $20.8 \%$ & $66.5 \%$ & $9.1 \%$ & $100.0 \%$ \\
\hline \multirow{2}{*}{$\begin{array}{ll}\text { Drugs } & \text { and } \\
\text { substance } & \end{array}$} & Count & 5 & 7 & 119 & 9 & 140 \\
\hline & $\%$ of Total & $3.60 \%$ & $5.00 \%$ & $85.0 \%$ & $6.4 \%$ & $100.0 \%$ \\
\hline $\begin{array}{l}\text { Pearson Chi- } \\
\text { Square } X(\text { Cal })^{2}\end{array}$ & $x^{2}=118.473$ & $d f=2$ & $p=0.000<0.05$ & & & \\
\hline
\end{tabular}

Source: Field Data (2018)

The study results in Table 14 indicated that out of 231 students faced with financial challenges $29(12.6 \%)$ were year 1 students, 53 (22.9\%) were year 2, 131 (56.7\%) were year 3 and 18 $(7.8 \%)$ were year 4 students. Out of 204 students facing social and interpersonal challenges 7 (3.4\%) were year 1 students, 48 (23.5\%) were year 2 students, 131 (64.2\%) were year 3 students and $18(8.8 \%)$ were year 4 students. Out of 197 students facing academic challenges 7 (3.6\%) were year 1 students, 41 (20.8\%) were year 2 students, 131 (66.5\%) were year 3 students and 18 (9.1\%) were year 4 students. Out of 140 students facing Drugs and substance challenges 5 (3.6\%) were year 1 students, 7 (5.0\%) were year 2 students, 119 (85.0\%) were year 3 students and $9(6.4 \%)$ were year 4 students. This implies that all years of study from year 1 to 4 who participated in the study faces financial, social and interpersonal, academic and drugs and substance challenges. However, year 3 was the majority faced by these challenges. Pearson chi-square test was then administered to establish whether there is an association between year of study and challenges faced. Pearson Chi-Square $X(C a l){ }^{2}$ value was found to be less than $p$ value $(p=0.000<0.05)$ which indicated that there was a significant relationship between year of study and university student's challenges.

The study results were in agreement with Abdullah, Elias, Mahyuddin \& Uli (2009) who indicated that students who are able to adjust well in campus while progressing in their academic level are found to display greater academic performance compared to those who have difficulty to adjust to university life. Students joining universities need every support to ensure that they settle fast with a smooth transition to the university life. 


\section{Summary, Conclusions and Recommendations Summary of the Findings}

The study results on the gender of the respondent's showed that majority of female responded to the study findings, despite this, both genders were well represented. Both genders represent all area of specialization in medical school and all range from age 15 to 34 years. The study collected data from year one to year four where most of the respondents were in year 3 of their studies implying that they understood the challenges experienced by students in the university. Under marital status the study found out that majority of respondents were single and few were married. The study collected data from both Christians and Islam.

\section{Discussion of Findings}

\section{Challenges that Students Face at the University}

The study results revealed that students face more than one challenge while in school which to some extent they have to seek for professional services. These concur with study done by Rekha, Swamy and Ravikumar (2017) who indicated that University students face a myriad of challenges. Adapting to the social and the physical environment constitutes one of the main challenges. Adjustment to new peer groups, academic atmosphere, loose family contact, and financial problems are some of the specific challenges. The study agrees with study finding of Sikolia and Lutomia (2002) which emphasized those students faces financial challenges in university which need assistance to cater for things their parents cannot provide.

The study also noted that both genders experiences different challenges while at campus. The study results concur with English, Davis, Wei and Gross (2017) who suggested that despite both gender experiencing different challenges in campus male are slightly affected because females are more likely than males to become counselling clients. As a result, women are more willing than men to reveal highly personal and vulnerable information about themselves to counsellors which will reduces the vulnerability to crisis.

This is in line with the finding on cross tabulation that both genders face financial, social and interpersonal, academic, drugs and substance challenges while in campus. The study findings concur with Gegato (2007) who noted that student's faces different challenge while in campus such as social interaction challenges and insufficient allowance which is one of the leading problems of college students.

There was a significant relationship between area of specialization and university student's challenges. This is in line with the finding of cross tabulation that students from all area of specialization in college of health sciences faces financial, social and interpersonal, academic and drugs and substance challenges. The study concurs with Dyrbye et al (2006) who found out that there was evidence of a high prevalence of depression and anxiety among medical students because of challenges they faced while in campus. They indicated challenges such as transition from preclinical to clinical training, financial and drug abuse. These findings also were in agreement with Gentile et al (2009) who noted that the most common sources of stress for college students were related to financial, social and interpersonal, vastness of syllabus, tests/exams, and lack of time to complete school assignment and drugs abuse.

The study findings revealed that all years of study from year 1 to 4 who participated in the study faces financial, social and interpersonal, academic and drugs and substance challenges. However, year 3 was the majority faced by these challenges. Therefore, gives an implication that there was a significant relationship between year of study and university student's challenges. This is in line with the finding of cross tabulation that all years of study from year 
1 to 4 who participated in the study faces financial, social and interpersonal, academic and drugs and substance challenges. However, year 3 was the majority faced by these challenges. Study findings agrees with results of Gentile et al (2009) which noted that third year students inevitably put medical students in contact with patients who have terminal illnesses. They also noted that the end of third year and the beginning of fourth year may bring stressors related to career choices, interviewing for residencies, and the second medical licensing board examination.

The third year of medical school was studied by Haglund et al (2009) and found out that many students in year 3 reported facing challenges such as personal mistreatment, financial, transition from preclinical to clinical training and substance abuse.

\section{Conclusions of the Study}

Based on the research findings, the researcher concludes that the challenges faced by students were finance, social and interpersonal, academic, drug and substance abuse among others. This is because medical school is inherently a stressful, challenging academic experience, which may make medical students vulnerable to depression, anxiety, and burnout hence resorts in seeking professional counselling services.

\section{Recommendations of the Study}

The counselling department should be aware of the challenges facing the students in order for them to advise accordingly. They should also ensure that the services are readily available, accessible at every medical school for those who need them. The professional counsellors should explore and assess student's individual personality traits, temperaments, and coping styles in order to enhance their attitude and perception.

\section{Reference}

Abdullah, M. C., Elias, H., Mahyuddin, R., \& Uli, J. (2009). Adjustment amongst first year students in a Malaysian university. European Journal of social sciences, 8(3), 496-505.

Aubrey, D. G., \& Emery, K. O. (1983). Eigenanalysis of recent United States sea levels. Continental Shelf Research, 2(1), 21-33.

Beck, J. (2008). Meritocracy, citizenship and education: New Labour's legacy. Continuum Intl Pub Group.

Best, J. W., \& Kahn, J. V. (1998). Research in education, Boston. Allyn and Bascon.

Bowers, P. (2002). African theology: Its history, dynamics, scope and future. Africa Journal of Evangelical Theology, 21(2), 109-126.

Carson, T. L. (2010). Lying and deception: Theory and practice. Oxford University Press.

Chesire, A. M. (2012). The self-concept and academic performance of institutionalized and non-institutionalized HIV/AIDS orphaned children in Kisumu municipality. Journal of Alternative Perspectives in the Social Sciences, 4(1), 242-257.

Cochran, W. G. (1940). The estimation of the yields of cereal experiments by sampling for the ratio of grain to total produce. The journal of agricultural science, 30(2), 262-275.

Creswell, J. W. (2011). Controversies in mixed methods research. The Sage handbook of qualitative research, 4, 269-284.

Davelaar, E. J., Goshen-Gottstein, Y., Ashkenazi, A., Haarmann, H. J., \& Usher, M. (2005). The demise of short-term memory revisited: empirical and computational investigations of recency effects. Psychological review, 112(1), 3. 
Dent, M., \& Whitehead, S. (Eds.). (2013). Managing professional identities: Knowledge, performativities and the'new'professional (Vol. 19). Routledge.

Dobson, K. S., \& Block, L. (1988). Historical and philosophical bases of cognitive behavioural theories. Handbook of Cognitive Behavioural Therapies.

Dyrbye, L. N., Thomas, M. R., \& Shanafelt, T. D. (2006). Systematic review of depression, anxiety, and other indicators of psychological distress among US and Canadian medical students. Academic medicine, 81(4), 354-373.

Eisenberg, D., Hunt, J., \& Speer, N. (2013). Mental health in American colleges and universities: variation across student subgroups and across campuses. The Journal of nervous and mental disease, 201(1), 60-67.

Eisenberger, T., Di Donato, N., Baig, S. M., Neuhaus, C., Beyer, A., Decker, E., ... \& Bolz, H. J. (2014). Targeted and Genomewide NGS Data Disqualify Mutations in MYO $1 \mathrm{~A}$, the "DFNA 48 Gene", as a Cause of Deafness. Human mutation, 35(5), 565-570.

English, T., Davis, J., Wei, M., \& Gross, J. J. (2017). Homesickness and adjustment across the first year of college: A longitudinal study. Emotion, 17(1), 1.

Fall, K. A., Levitov, J. E., Jennings, M., \& Eberts, S. (2000). The public perception of mental health professions: An empirical examination. Journal of Mental Health Counseling, 22(2), 122.

Farberman, R. K. (1997). Public attitudes about psychologists and mental health care: Research to guide the American Psychological Association public education campaign. Professional Psychology: Research and Practice, 28(2), 128.

Fawzy, M., \& Hamed, S. A. (2017). Prevalence of psychological stress, depression and anxiety among medical students in Egypt. Psychiatry research, 255, 186-194.

Gegato Jr, B. N. (2007). Isang Kwalitibong Pagsusuri ng mga Nilalaman sa mga Piling Kathang Awitin ni George M. Canseco: Lunsaran sa mga Kagamitang Pampagtuturo. Kayamag, 2(1), 1-1.

Hahn, S. L. (1996). Hilbert transforms in signal processing (Vol. 2). Boston: Artech House.

Hanson, R. K. (1998). What do we know about sex offender risk assessment?. Psychology, Public Policy, and Law, 4(1-2), 50.

Hasin, D. S., Goodwin, R. D., Stinson, F. S., \& Grant, B. F. (2005). Epidemiology of major depressive disorder: results from the National Epidemiologic Survey on Alcoholism and Related Conditions. Archives of general psychiatry, 62(10), 1097-1106.

Heppner, P. P., Casas, J. M., Carter, J., \& Stone, G. L. (2000). The maturation of counseling psychology: Multifaceted perspectives, 1978-1998. Handbook of counseling psychology, 3, 3-49.

Horwitz, A. V., Widom, C. S., McLaughlin, J., \& White, H. R. (2001). The impact of childhood abuse and neglect on adult mental health: A prospective study. Journal of health and social behavior, 184-201.

Huddleston, W., Keenan, K., \& Ernest, B. (2013). Relations among visual strategies, force fluctuations, and attention during a force-matching task. Perceptual and motor skills, $117(3), 775-800$.

Jamshed, S. (2014). Qualitative research method-interviewing and observation. Journal of basic and clinical pharmacy, 5(4), 87.

Kennedy, S., Kenny, A., \& O'Meara, P. (2015). Student paramedic experience of transition into the workforce: a scoping review. Nurse Education Today, 35(10), 1037-1043. 
Kessler, R. C., Berglund, P., Demler, O., Jin, R., Merikangas, K. R., \& Walters, E. E. (2005). Lifetime prevalence and age-of-onset distributions of DSM-IV disorders in the National Comorbidity Survey Replication. Archives of general psychiatry, 62(6), 593-602.

Kitzrow, M. A. (2009). The mental health needs of today's college students: Challenges and recommendations. NASPA Journal, 46(4), 646-660.

Kombo, D. K., \& Tromp, D. L. (2006). Proposal and thesis writing: An introduction. Nairobi: Paulines Publications Africa, 5, 814-30.

Lutomia, G., \& Sikolia, L. (2002). Guidance and counselling in schools and colleges. Uzima Publishing House.

Marlatt, G. A., \& Witkiewitz, K. (2010). Update on harm-reduction policy and intervention research. Annual Review of Clinical Psychology, 6, 591-606.

Marlatt, G. A., \& Witkiewitz, K. (2010). Update on harm-reduction policy and intervention research. Annual Review of Clinical Psychology, 6, 591-606.

Mugenda, O. M., \& Mugenda, A. G.(2003). Research methods.

Nugent, T., \& Jones, D. T. (2009). Transmembrane protein topology prediction using support vector machines. BMC bioinformatics, 10(1), 159.

O’Grady, N. P., Barie, P. S., Bartlett, J. G., Bleck, T., Carroll, K., Kalil, A. C., ... \& Masur, H. (2008). Guidelines for evaluation of new fever in critically ill adult patients: 2008 update from the American College of Critical Care Medicine and the Infectious Diseases Society of America. Critical care medicine, 36(4), 1330-1349.

Robitschek, C., \& Spering, C. C. (2012). A critical review of positive psychology theory and research. In APA handbook of counseling psychology, Vol. 1: Theories, research, and methods. (pp. 329-344). American Psychological Association.

Saban, I. (2003). Minority rights in deeply divided societies: A framework for analysis and the case of the Arab-Palestinian minority in Israel. NYUJ Int'I. L. \& Pol., 36, 885.

Saunders, M., Lewis, P., \& Thornhill, A. (2009). Research methods for business students. Essex. Financial Times/Prentice Hall.

Singh, H. P., \& Tailor, R. (2003). Use of known correlation coefficient in estimating the finite population mean. Statistics in transition, 6(4), 555-560.

Starovoytova, D., \& Cherotich, S. (2016). Analysis of Masculinities Across Engineering Disciplines. Research on Humanities and Social Sciences, 6(18).

Thampy, H., \& Danczak, A. (2015). GP training for patient safety: understanding, classifying and mapping. Education for Primary Care, 26(5), 326-327.

Wampold, B. E., Lichtenberg, J. W., \& Waehler, C. A. (2002). Principles of empirically supported interventions in counseling psychology. The Counseling Psychologist, 30(2), 197-217.

Whiteley, J. M. (1984). Counseling Psychology: A Historical Perspective. Counseling Psychologist, 12(1), 3-109. 